\title{
Effects of Cocaine-Kindling on the Expression of NMDA Receptors and Glutamate Levels in Mouse Brain
}

\author{
Rafal M. Kaminski · Juan F. Núñez-Taltavull • Bogusława Budziszewska • \\ Władysław Lasoń · Maciej Gasior • Agustin Zapata • \\ Toni S. Shippenberg $\cdot$ Jeffrey M. Witkin
}

Accepted: 23 September 2010/Published online: 7 October 2010

(C) The Author(s) 2010. This article is published with open access at Springerlink.com

\begin{abstract}
In the present study we examined the effects of cocaine seizure kindling on the expression of NMDA receptors and levels of extracellular glutamate in mouse brain. Quantitative autoradiography did not reveal any changes in binding of $\left[{ }^{3} \mathrm{H}\right]$ MK-801 to NMDA receptors in several brain regions. Likewise, in situ hybridization and Western blotting revealed no alteration in expression of the NMDA receptor subunits, NR1 and NR2B. Basal overflow of glutamate in the ventral hippocampus determined by microdialysis in freely moving animals also did not differ between cocaine-kindled and control groups. Perfusion with the selective excitatory amino acid transporter inhibitor, pyrrolidine-2,4-dicarboxylic acid (tPDC, $0.6 \mathrm{mM}$ ), increased glutamate overflow confirming transport inhibition. Importantly, $\mathrm{KCl}$-evoked glutamate overflow under tPDC perfusion was significantly higher in cocaine-kindled mice than in control mice. These data suggest that enhancement of depolarization stimulated glutamate
\end{abstract}

R. M. Kaminski · M. Gasior · J. M. Witkin

Drug Development Group, Behavioral Neuroscience Branch, National Institute on Drug Abuse, NIH, 5500 Nathan Shock Drive, Baltimore, MD 21224, USA

R. M. Kaminski · J. F. Núñez-Taltavull · A. Zapata ·

T. S. Shippenberg

Integrative Neuroscience Section, Behavioral Neuroscience Branch, National Institute on Drug Abuse, NIH, 5500 Nathan Shock Drive, Baltimore, MD 21224, USA

B. Budziszewska · W. Lasoń

Department of Experimental Neuroendocrinology, Institute of Pharmacology, Polish Academy of Sciences, Kraków, Poland

R. M. Kaminski $(\bowtie)$

CNS Research, Epilepsy Pharmacology, UCB Pharma S.A. Chemin du Foriest, R9, B-1420 Braine-l'Alleud, Belgium

e-mail: rafal.kaminski@ucb.com release may be one of the mechanisms underlying the development of increased seizure susceptibility after cocaine kindling.

Keywords Cocaine $\cdot$ Seizure $\cdot$ Kindling $\cdot$ Glutamate . Microdialysis $\cdot$ NMDA receptor

\section{Introduction}

Glutamate, the primary excitatory neurotransmitter in the mammalian brain, plays a key role in seizure generation and epilepsy. Pharmacological inhibition of glutamatergic neurotransmission provides protection against seizures in a host of experimental models [1]. Blockade of the NMDA receptor by different classes of selective antagonists protects against cocaine-induced convulsions [2-7]. Furthermore, NMDA receptor antagonists inhibit the expression and development of cocaine-kindled seizures $[8,9]$.

A pivotal role of glutamatergic neurotransmission has been demonstrated in seizure kindling models and numerous reports indicate altered expression of glutamate receptors in various brain regions of kindled-animals [for review see Löscher, 10]. Moreover, the extracellular levels of glutamate are elevated in various brain regions of fullykindled animals [11-15]. These changes are thought to underlie the development of seizure kindling in various models.

Cocaine kindling is characterized by increased seizure response to subsequent administrations of the drug [16, 17]. This paradigm is akin to other well characterized models of kindling, i.e. amygdala- or PTZ-kindled seizures [18, 19]. However, glutamatergic neurotransmission is relatively less characterized in this model and important questions remain as to the role of glutamate in cocaine kindled 
seizures. In the present report, we studied the changes in mRNA and protein expression of NMDA receptor subunits, NR1 and NR2B, together with quantitative [ $\left.{ }^{3} \mathrm{H}\right] \mathrm{MK}-801$ autoradiography in mice kindled by repeated administration of cocaine. Basal and depolarization-induced glutamate overflow was quantified in control and cocainekindled mice using in vivo brain microdialysis.

\section{Experimental Procedure}

\section{Animals}

Male Swiss Webster mice (Taconic Farms, Germantown, NY), weighing 25-35 g, were housed five per cage with free access to food and water. Mice were kept in a vivarium under controlled laboratory conditions (temperature $22-26^{\circ} \mathrm{C}$, humidity $40-50 \%$ ) with an artificial 12-h light/ dark cycle. All animals were allowed to acclimate for at least 5 days before testing. The experimental groups consisted of 6-8 animals. The experiments were performed during the light cycle after at least 30-min acclimation to the experimental room. Mice were returned to their home cage and placed in the vivarium after daily testing.

Animals used in these studies were maintained in facilities fully accredited by the American Association for Accreditation of Laboratory Animal Care and were tested under approved protocols from the Animal Care and Use Committee of the National Institute of Drug Abuse, under guidance by the Guide for Care and Use of Laboratory Animals (National Research Council, 1996, National Academy Press, Washington, DC).

\section{Treatment}

The animals were kindled with cocaine (National Institute on Drug Abuse, Baltimore, MD) at a dose of $60 \mathrm{mg} / \mathrm{kg}$ (i.p.; one injection per day) for 5 consecutive days as described by Miller et al. [16]. Each day immediately following cocaine injection every mouse was individually placed in Plexiglas containers $(14 \times 25 \times 36 \mathrm{~cm})$ for observation. The presence of convulsions was recorded for $30 \mathrm{~min}$ following injection. Cocaine-induced convulsions were defined as the occurrence of clonic seizures accompanied by loss of the righting reflex for at least $5 \mathrm{~s}$. The development of kindling was reflected by monotonic and statistically significant increases in the number of mice exhibiting seizures upon repeated treatments with cocaine [16]. After a 5-day washout, when the susceptibility to the convulsant effect of cocaine is still significantly increased [16], the mice were sacrificed and their brains were removed for receptor studies (described below). Another group of animals was kindled under the same protocol and used for microdialysis studies after the 5-day washout from cocaine (described below). Control animals always received i.p. saline injections instead of cocaine and underwent the same experimental manipulations as cocaine-kindled groups.

\section{Preparation of Brain Tissue}

The animals were sacrificed 5 days after a 5-day cocaine washout and their brains were removed rapidly, quickly frozen on dry ice, and stored at $-70^{\circ} \mathrm{C}$. Twelve- $\mu \mathrm{m}$ thick tissue sections were cut in a cryostat (Shandon, UK) and thaw-mounted onto poly-L-lysine-coated microscope slides. Sections were taken at a level of hippocampus and striatum. Slide mounted sections were stored in slide boxes at $-70^{\circ} \mathrm{C}$ until used in assays.

\section{Quantitative Autoradiography of $\left[{ }^{3} \mathrm{H}\right] \mathrm{MK}-801$}

On the day of the experiment, before incubation, frozen tissue sections were slowly warmed in a refrigerator $\left(4^{\circ} \mathrm{C}\right)$ then thoroughly blown dry with cool air for $5 \mathrm{~min}$. Sections were preincubated (pre-wash) in a $5 \mathrm{mM}$ Tris-Hcl buffer (pH 7.4) containing $2.5 \mathrm{mM} \mathrm{CaCl} 2$ at $5^{\circ} \mathrm{C}$ for $10 \mathrm{~min}$. Subsequently, they were incubated in a $5 \mathrm{mM}$ Tris- $\mathrm{Hcl}$ buffer ( $\mathrm{pH} 7.4$ ) containing $5 \mu \mathrm{M}$ spermidine, $5 \mu \mathrm{M}$ L-glycine, $5 \mu \mathrm{M}$ glutamate and $6 \mu \mathrm{M}\left[{ }^{3} \mathrm{H}\right] \mathrm{MK}-801$ (NEN; sp. act. $61 \mathrm{Ci} / \mathrm{mmol}$ ) for $90 \mathrm{~min}$ at room temperature. Nonspecific binding was determined as binding in the presence of $100 \mu \mathrm{M}$ unlabeled MK-801. After incubations sections were washed 3 times in fresh, ice-cold $5 \mathrm{mM}$ Tris-Hcl buffer ( $\mathrm{pH} 7.4)$ then in ice-cold water and twice in ice-cold $2.5 \%$ glutaraldehyde in acetone and then dried in a stream of cold air. All sections were placed in boxes along with desiccant overnight before being placed into cassettes with tritium-sensitive film. Dried sections were exposed to $\left[{ }^{3} \mathrm{H}\right]$ Hyperfilm (Amersham) along with tritium standards and stored in an X-ray film cassette for 4 weeks at $4^{\circ} \mathrm{C}$. Autoradiograms were developed with Kodak D-19 developer and fixed with Kodak Fixer at $18^{\circ} \mathrm{C}$. Quantification analysis of the resulting autoradiographic images was performed by using the MCID image analysis system (Imaging Research Inc., Canada). The obtained values were compared by Student's $t$-test.

\section{In Situ Hybridization}

A series of five consecutive coronal sections (12 $\mu$ m-thick) was thaw-mounted onto chromalum-pretreated slices, postfixed in a $4 \%$ formaldehyde for $10 \mathrm{~min}$, and processed for in situ hybridization according to Young et al. [20]. The 
anti-sense NR1 and NR2B oligonucleotide probes were complementary to bases $375-420$ of the rat NR1 cDNA [21] and to bases 557-572 of the rat NR2B receptor mRNA [22]. Probes were labeled using $\left[{ }^{35} \mathrm{~S}\right] \mathrm{dATP}(1,200 \mathrm{Ci} /$ mmol, NEN) to obtain a specific activity of about $2 \times 10^{6} \mathrm{Ci} / \mathrm{mol}$. Pre-hybridization treatment consisted of acetylation and dehydration. The sections were then hybridized with NR1 and NR2B oligonucleotide probe $\left(1 \times 10^{6}\right.$ c.p.m. $\left./ 25 \mu \mathrm{l}\right)$ for $20 \mathrm{~h}$ at $37^{\circ} \mathrm{C}$ in a humidified incubator. After washing at $40^{\circ} \mathrm{C}$, the sections were exposed to a Hyperfilm MP (Amersham) at room temperature for 21 days. After hybridization, washing out and autoradiography of the brain slices, quantification of the signals on film was performed using MCID image analysis system (Imaging Research Inc., Canada). Hybridization of the NR1 and NR2B oligonucleotide probes was recorded as a mean density after subtraction of the film background density. The mean optical density values were obtained by averaging the measurements from autoradiograms of the brain sections, obtained from six animals. The obtained values were compared by Student's $t$-test.

\section{Western Blotting}

Frontal cerebral cortex, hippocampus and striatum were dissected from mice brain and were stored at $-80^{\circ} \mathrm{C}$ until processing. The tissue was homogenized in 20 volumes of ice-cold $0.32 \mathrm{M}$ sucrose at $0^{\circ} \mathrm{C}$, centrifuged at $1,000 \times g$ for $10 \mathrm{~min}$ at $4^{\circ} \mathrm{C}$ and the supernatant was then centrifuged at $10,000 \times g$ for $20 \mathrm{~min}$ at $4^{\circ} \mathrm{C}$. The membrane pellet was resuspended and washed in 30 volumes of $50 \mathrm{mM}$ Tris-Hcl $(\mathrm{pH}=7.4)$ and the final pellet (resuspended in 7 volumes of buffer) was used for Western blot analysis [23]. The protein concentration was determined by the method of Lowry et al. [24]. Aliquots of $10 \mu \mathrm{g}$ of protein per line (cerebral cortex, hippocampus) or $15 \mu \mathrm{g}$ of protein per line (striatum) were separated by $7 \%$ SDS-PAGE and transferred to polyvinylidene fluoride membranes (PVDF Western Blotting Membranes, Boehringer Mannheim, Germany). Blots were incubated overnight at $4^{\circ} \mathrm{C}$ with rabbit anti-glutamate receptor NR1 (1:2,500; Sigma, Saint Louis, USA) or with rabbit anti-glutamate receptor NR2B (RBI, Natick, USA) followed by incubation for $30 \mathrm{~min}$ at room temperature with horseradish peroxidase-conjugated anti-rabbit secondary antibodies (40 mU/ml, Boehringer Mannheim, Germany). Proteins were visualized with enhanced chemiluminescence (BM Chemiluminescence Western Blotting Kit, Boehringer Mannheim, Germany). The relative changes in the protein levels were evaluated by measuring the intensity of the immunoreactive bands using the Image Gauge ver. 3.11 system (FUJI Medical Systems, USA). The obtained values were compared by Student's $t$-test.
In Vivo Microdialysis

Upon completion of cocaine-kindling (24 h after the last cocaine injection) animals were anesthetized with sodium pentobarbital ( $75 \mathrm{mg} / \mathrm{kg}$ i.p.) and placed in a stereotaxic frame (David Kopf, Topanga, CA) adapted for the mouse. A microdialysis guide cannula (CMA11, CMA/Microdialysis, North Chelmsford, MA) was aimed at the ventral hippocampus, according to the atlas of Paxinos and Franklin [25]. The coordinates, relative to bregma, were: P: $-2.8 \mathrm{~mm}, \mathrm{~L}: \pm 3.0 \mathrm{~mm}, \mathrm{~V}:-2.0 \mathrm{~mm}$, calculated for $2 \mathrm{~mm}$ membrane length probes. The guide cannula was fixed to the skull with cranioplastic cement (Geristore, Santa Maria, CA) and secured with dental acrylic (Lang Dental MGF. Inc., Wheeling, Illinois). After surgery, mice were individually housed in the animal facility room for recovery. Animals were given a 4 days recovery period after surgery, prior to the commencement of the experiment. Twelve hours before starting the experiments, microdialysis probes (CMA/11, CMA Microdialysis, North Chelmsford, MA) were connected to the microinfusion pump (CMA/102) via a quartz-lined, low resistance swivel (375/D/22QM, Instech, Plymouth Meeting, PA) and flushed with an artificial cerebrospinal fluid (aCSF: $145 \mathrm{mM} \mathrm{NaCl}, 2.8 \mathrm{mM} \mathrm{KCl}$, $1.2 \mathrm{mM} \mathrm{Ca}_{2} \mathrm{Cl}, 1.2 \mathrm{mM} \mathrm{Mg}_{2} \mathrm{Cl}, 5.4 \mathrm{mM}$ D-glucose, $\mathrm{pH} 7.2$ adjusted with $\mathrm{NaOH} 0.5 \mathrm{M}$ ). Probes were then slowly inserted into the guide cannulae and mice were placed into the plexiglass chambers where food and water were freely available. The probes were perfused overnight at a flow rate of $0.6 \mu \mathrm{l} / \mathrm{min}$. The next morning and after a $1.5 \mathrm{~h}$ equilibration period with fresh aCSF, dialysis samples were collected every $10 \mathrm{~min}$. Three basal samples were collected. The aCSF was switched to an aCSF containing $0.6 \mathrm{mM}$ of the selective glutamate transporter inhibitor, Ltrans-pyrrolidine-2,4-dicarboxylic acid (tPDC; Sigma) [26]. Four dialysate samples were then collected for determination of potassium-evoked glutamate levels. A high- $\mathrm{K}^{+}$aCSF $(100 \mathrm{mM} \mathrm{KCl})$ containing $0.6 \mathrm{mM}$ of tPDC was perfused and 4 additional samples were collected [27].

\section{Analysis of Dialysate Glutamate Levels}

Glutamate levels were quantified using a pre-column derivatization reaction with o-Phthalaldehyde followed by HPLC with fluorimetric detection. Briefly, $4 \mu \mathrm{l}$ of dialysate samples were diluted in $13 \mu$ of borax ( $\mathrm{pH} 10.5)$. Then, $3 \mu \mathrm{l}$ of derivatizing reagent $(0.4 \mathrm{M}$ borate, $40 \mu \mathrm{M}$ oPhthaldialdehyde and $0.4 \mathrm{M}$ 2-mercaptoethanol) was added. After a $60 \mathrm{~s}$ reaction period, derivatized sample was injected with a CMA/200 refrigerated microinjector (CMA Microdialysis, North Chelmsford, MA) into the HPLC system. Separation of glutamate was achieved by using a BAS microbore C18 column $(100 \times 1 \mathrm{~mm}, 5 \mu \mathrm{m})$. The 
mobile phase $(0.1 \mathrm{M}$ sodium acetate, $6 \%$ acetonitrile $(\mathrm{v} / \mathrm{v})$, adjusted to $\mathrm{pH} 6.0$, filtered through a $0.22 \mu \mathrm{m}$ nylon filter and degassed) was pumped with a BAS PM-80 pump (BAS, West Lafayette, IN) at a flow rate of $160 \mu \mathrm{l} / \mathrm{min}$, that was achieved through a splitter-flow restrictor. Glutamate was detected using a BAS Fluorescence detector (FL-45) with the following wavelengths settings: excitation-330 $\eta \mathrm{m}$ and emission-440 $\eta \mathrm{m}$. Neurotransmitter dialysate levels were quantified by external standard curve calibration. Limit of detection was $0.1 \mu \mathrm{M}$. The results are expressed in $\mu \mathrm{M}$ as means \pm SEM. The area under the curve was calculated for each treatment group and compared by Student's $t$-test.

\section{Results}

Quantitative autoradiography of $\left[{ }^{3} \mathrm{H}\right]$ MK-801 did not reveal changes in radioligand binding to any brain region of cocaine-kindled mice. Thus, comparable values were obtained in control and cocaine-kindled mice in hippocampus (both CA1 and CA3 regions), nucleus accumbens (both shell and core), dorsolateral and ventromedial striatum, sensory, motor and cingulate cortex (Table 1).

In situ mRNA hybridization of NR1 and NR2B subunits measured in hippocampus, striatum and frontal cortex also remained unaltered in cocaine-kindled mice in comparison to control group (Table 2). Finally, protein levels of NR1 and NR2B subunits were unchanged by cocaine-kindling as indicated by quantitative Western blotting (Table 3).

Table 1 Effect of cocaine kindling on specific binding of $\left[{ }^{3} \mathrm{H}\right] \mathrm{MK}$ 801 to mouse brain structures in cocaine kindled and control mice

\begin{tabular}{lcl}
\hline $\begin{array}{l}\text { Brain } \\
\text { structure }\end{array}$ & $\begin{array}{l}\text { Control } \\
\text { (optical density } \\
\text { units) }\end{array}$ & $\begin{array}{l}\text { Cocaine-kindled } \\
\text { (optical density units) }\end{array}$ \\
\hline HPC-CA1 & $27.3 \pm 7.3$ & $32.0 \pm 8.0$ \\
HPC-CA3 & $26.7 \pm 8.6$ & $27.2 \pm 6.1$ \\
N. ACC-shell & $9.5 \pm 4.2$ & $10.1 \pm 4.9$ \\
N. ACC-core & $16.2 \pm 5.6$ & $16.9 \pm 5.0$ \\
ST-DL & $16.3 \pm 5.0$ & $17.8 \pm 4.9$ \\
ST-VM & $17.6 \pm 5.3$ & $19.2 \pm 5.1$ \\
Sensory cortex & $37.3 \pm 12.5$ & $37.5 \pm 11.6$ \\
Motor cortex & $36.0 \pm 11.5$ & $40.1 \pm 8.6$ \\
Cingulate cortex & $48.0 \pm 15.9$ & $54.8 \pm 8.0$
\end{tabular}

Values (optical density units) are given as mean \pm SEM from 6 animals. HPC-CA1 hippocampus (CA1 region), HPC-CA3 hippocampus (CA3 region), N. ACC-shell nucleus accumbens (shell), $N$. $A C C$ - core nucleus accumbens (core), $S T-D L$ dorsolateral striatum, $S T-V M$ ventromedial striatum. The obtained values were compared between control and cocaine-kindled groups by Student's $t$-test. No statistically significant differences were observed $(P>0.05)$
Table 2 In situ mRNA hybridization of NR1 and NR2B subunits of NMDA receptors in different brain regions of cocaine kindled and control mice

\begin{tabular}{lll}
\hline Brain structure & $\begin{array}{l}\text { Control } \\
\text { (optical density units) }\end{array}$ & $\begin{array}{l}\text { Cocaine-kindled } \\
\text { (optical density units) }\end{array}$ \\
\hline NR1 & & \\
HPC-CA1 & $0.26 \pm 0.04$ & $0.29 \pm 0.05$ \\
HPC-CA3 & $0.28 \pm 0.05$ & $0.34 \pm 0.05$ \\
HPC-DG & $0.28 \pm 0.03$ & $0.31 \pm 0.04$ \\
Striatum & $0.11 \pm 0.01$ & $0.14 \pm 0.01$ \\
Frontal cortex & $0.13 \pm 0.02$ & $0.16 \pm 0.01$ \\
NR2B & & \\
HPC-CA1 & $0.087 \pm 0.007$ & $0.081 \pm 0.006$ \\
HPC-CA3 & $0.096 \pm 0.006$ & $0.096 \pm 0.006$ \\
HPC-DG & $0.138 \pm 0.009$ & $0.127 \pm 0.010$ \\
Striatum & $0.030 \pm 0.001$ & $0.038 \pm 0.004$ \\
Frontal cortex & $0.037 \pm 0.001$ & $0.037 \pm 0.003$ \\
\hline
\end{tabular}

Values (optical density units) are given as mean \pm SEM from 6 animals. Abbreviations used: $H P C-C A 1$ hippocampus (CA1 region); $H P C$-CA3 hippocampus (CA3 region), $H P C-D G$ hippocampus (dentate gyrus). $e$ nucleus accumbens (core), $S T-D L$ dorsolateral striatum, $S T-V M$ ventromedial striatum. The obtained values were compared between control and cocaine-kindled groups by Student's $t$-test. No statistically significant differences were observed $(P>0.05)$

Table 3 Protein levels of NR1 and NR2B subunits of NMDA receptors measured by Western blotting in cocaine kindled and control mice

\begin{tabular}{lcc}
\hline Brain structure & $\begin{array}{l}\text { Control (optical } \\
\text { density units) }\end{array}$ & $\begin{array}{l}\text { Cocaine-kindled } \\
\text { (optical density units) }\end{array}$ \\
\hline NR1 & & \\
Hippocampus & $99,754 \pm 26,162$ & $116,742 \pm 19,359$ \\
$\quad$ Striatum & $145,738 \pm 42,600$ & $159,528 \pm 50,676$ \\
Frontal Cortex & $94,368 \pm 7,455$ & $88,786 \pm 10,390$ \\
NR2B & & \\
Hippocampus & $152,540 \pm 5,464$ & $172,300 \pm 11,248$ \\
Striatum & $260,620 \pm 48,487$ & $252,520 \pm 84,450$ \\
Frontal cortex & $110,600 \pm 3,930$ & $108,496 \pm 12,478$ \\
\hline
\end{tabular}

Values (optical density units) are given as mean \pm SEM from 6 animals. The obtained values were compared between control and cocaine-kindled groups by Student's $t$-test. No statistically significant differences were observed $(P>0.05)$

Microdialysis studies revealed no difference $(P>0.05)$ between control and cocaine-kindled groups in basal glutamate overflow in the ventral hippocampus (Fig. 1a). Rapid transporter-mediated uptake may mask the detection of changes in glutamate release [28], therefore a selective excitatory amino acid transporter inhibitor tPDC [26] was added to the perfusion medium for subsequent studies. 

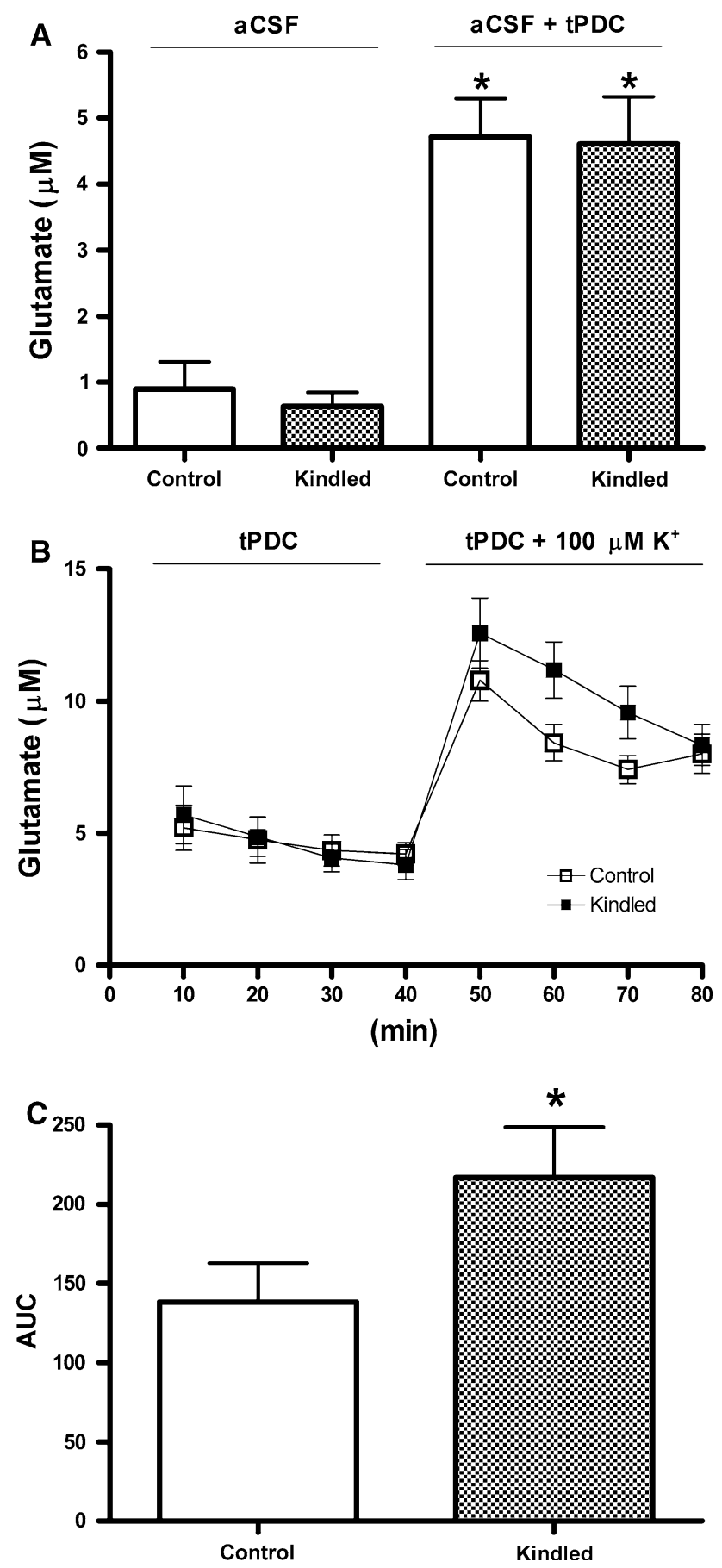

Fig. 1 Comparison of glutamate levels in the ventral hippocampus measured by brain microdialysis in freely moving cocaine-kindled and control mice. a basal glutamate levels during perfusion with normal aCSF and aCSF containing $0.6 \mathrm{mM}$ of glutamate uptake inhibitor, tPDC. $\mathbf{b}$ high potassium-evoked levels of glutamate in the presence of tPDC in the perfusate. $\mathbf{c}$ area under the curve (AUC) calculated for the graph in $\mathbf{b}$. $* P<0.05$ versus control group (Student's $t$-test)

tPDC caused significant (approximately fivefold) increase of glutamate levels in both kindled and control mice $(P<0.05)$ (Fig. 1a). However, the increase in glutamate levels caused by perfusion of tPDC was comparable in both groups of mice (Fig. 1a). In contrast, potassium-induced depolarization with co-perfusion of tPDC led to an increase of glutamate level $(P<0.05)$ in cocaine-kindled animals as compared to control mice (Fig. 1b, c).

\section{Discussion}

Since NMDA antagonists display protective activity against both acute [3] and chronic effects of cocaineinduced seizures $[8,9]$, we investigated whether NMDA receptors or presynaptic glutamate transmission is altered in cocaine-kindled mice. No significant alterations in the mRNA expression of NMDA receptor subunits or NMDA ligand binding were seen. Basal levels of glutamate also did not differ between kindled and control mice. However, perfusion of high-potassium aCSF together with tPDC revealed higher depolarization-evoked overflow of glutamate in cocaine-kindled mice.

Five days after completion of kindling, at the time when the susceptibility to cocaine-induced seizures is still increased [16], we found no changes in NMDA receptor binding. This observation is in agreement with previously published data regarding binding of a non-competitive NMDA antagonist, $\left[{ }^{3} \mathrm{H}\right] \mathrm{MK}-801$, in rat brain membranes following cocaine kindling [8]. However, binding of a competitive antagonist, $\left[{ }^{3} \mathrm{H}\right] \mathrm{CGP} 39653$, was significantly increased under the same conditions [8, 29]. Our results consistently show that in addition to the lack of changes in $\left[{ }^{3} \mathrm{H}\right] \mathrm{MK}-801$ binding assessed by quantitative autoradiography there were no changes in mRNA expression assessed by in situ hybridization and protein levels of key NMDA receptor subunits measured by Western blot. These results are in line with the fact that the expression of mRNA transcripts and protein for several NMDA receptor subunits is also not altered by electrical kindling [30, 31]. Together these findings indicate that cocaine kindled seizures, similarly to electrically kindled seizures, do not appear to be associated with changes in NMDA receptor expression. However, changes in expression of AMPA receptors have been reported during seizure kindling [32] and AMPA receptors antagonists are efficacious against cocaineinduced seizures [33]. Thus, it is possible that alteration in AMPA receptor expression may play a more important role in cocaine kindling, but this still remains to be determined.

Basal levels of glutamate measured by microdialysis are generally elevated in several brain regions of electricallyand chemically-kindled animals [11-14]. However, a study of Ueda and Tsuru [34] reported elevated glutamate levels in amygdala kindled animals, which was present for only few minutes after electrical stimulation. Basal levels of this neurotransmitter in the ventral hippocampus remained 
unaltered throughout kindling acquisition and in fullykindled rats [34]. Our study is the first to measure extracellular glutamate levels in cocaine-kindled animals. Similarly to the report by Ueda and Tsuru [34] we have found no changes in basal level of glutamate in this brain region. Perfusion with tPDC caused a several fold increase in glutamate levels as previously reported by Herrera-Marschitz, [27]. Although no difference between kindled and control mice in glutamate level measured under these conditions was observed, co-perfusion of a depolarizing concentration of $\mathrm{K}^{+}$with tPDC produced a significantly greater increase in glutamate overflow in cocaine-kindled mice versus control group. This observation is consistent with several studies performed in epileptic animals where the enhancement of depolarization stimulated glutamate release has been observed [12, 31, 35, 36]. Similar findings have been obtained in vitro in tissue obtained from patients with temporal lobe epilepsy [36]. It has been demonstrated that under basal conditions the uptake of glutamate from the extracellular space is very rapid, however when uptake transport is inhibited by tPDC then changes in glutamate release can be unmasked [28]. Collectively, these results indicate that depolarization-dependent release of glutamate is enhanced as a consequence of seizure kindling with cocaine. Future studies will determine whether similar mechanisms could also be responsible for alteration of seizure threshold after withdrawal from repeated administration of cocaine at sub-convulsant doses.

Changes in glutamatergic neurotransmission and alterations in glutamate receptor expression are thought to play an important role in the development of drug abuse, behavioral sensitization and withdrawal symptoms [37, 38]. Our data strongly suggest that glutamate neurotransmission is also enhanced as a consequence of cocaine-kindled seizures and may play an important role in this process.

Acknowledgments This research was supported by NIDA Intramural Research Program of NIH.

Open Access This article is distributed under the terms of the Creative Commons Attribution Noncommercial License which permits any noncommercial use, distribution, and reproduction in any medium, provided the original author(s) and source are credited.

\section{References}

1. Meldrum BS (1994) The role of glutamate in epilepsy and other CNS disorders. Neurology 44:S14-S23

2. Witkin JM, Tortella FC (1991) Modulators of N-methyl-Daspartate protect against diazepam- or phenobarbital-resistant cocaine convulsions. Life Sci 48:L51-L56

3. Witkin JM, Gasior M, Heifets B et al (1999) Anticonvulsant efficacy of N-methyl-D-aspartate antagonists against convulsions induced by cocaine. J Pharmacol Exp Ther 289:703-711
4. Zapata A, Gasior M, Geter-Douglass B et al (2003) Attenuation of the stimulant and convulsant effects of cocaine by 17-substituted-3-hydroxy and 3-alkoxy derivatives of dextromethorphan. Pharmacol Biochem Behav 74:313-323

5. Brackett RL, Pouw B, Blyden JF et al (2000) Prevention of cocaine-induced convulsions and lethality in mice: effectiveness of targeting different sites on the NMDA receptor complex. Neuropharmacology 39:407-418

6. Karler R, Calder LD (1992) Excitatory amino acids and the actions of cocaine. Brain Res 582:143-146

7. Rockhold RW, Oden G, Ho IK et al (1991) Glutamate receptor antagonists block cocaine-induced convulsions and death. Brain Res Bull 27:721-723

8. Itzhak Y, Stein I (1992) Sensitization to the toxic effects of cocaine in mice is associated with the regulation of N-methyl-Daspartate receptors in the cortex. J Pharmacol Exp Ther 262:464-470

9. Karler R, Calder LD, Chaudhry IA et al (1989) Blockade of "reverse tolerance" to cocaine and amphetamine by MK- 801 . Life Sci 45:599-606

10. Löscher W (1998) Pharmacology of glutamate receptor antagonists in the kindling model of epilepsy. Prog Neurobiol 54:721-741

11. Zhang WQ, Hudson PM, Sobotka TJ et al (1991) Extracellular concentrations of amino acid transmitters in ventral hippocampus during and after the development of kindling. Brain Res 540:315-318

12. Kaura S, Bradford HF, Young AM et al (1995) Effect of amygdaloid kindling on the content and release of amino acids from the amygdaloid complex: in vivo and in vitro studies. J Neurochem 65:1240-1249

13. Li Z, Yamamoto Y, Morimoto T, Ono J et al (2000) The effect of pentylenetetrazole-kindling on the extracellular glutamate and taurine levels in the frontal cortex of rats. Neurosci Lett 282:117-119

14. Minamoto Y, Itano T, Tokuda M et al (1992) In vivo microdialysis of amino acid neurotransmitters in the hippocampus in amygdaloid kindled rat. Brain Res 573:345-348

15. Mazzuferi M, Binaschi A, Rodi D et al (2005) Induction of B1 bradykinin receptors in the kindled hippocampus increases extracellular glutamate levels: a microdialysis study. Neuroscience 135:979-986

16. Miller KA, Witkin JM, Ungard JT et al (2000) Pharmacological and behavioral characterization of cocaine-kindled seizures in mice. Psychopharmacology (Berl) 148:74-82

17. Post RM, Kopanda RT (1975) Letter: cocaine, kindling, and reverse tolerance. Lancet 1:409-410

18. Goddard GV, McIntyre DC, Leech CK (1969) A permanent change in brain function resulting from daily electrical stimulation. Exp Neurol 25:295-330

19. Pinel JP, Cheung KF (1977) Controlled demonstration of metrazol kindling. Pharmacol Biochem Behav 6:599-600

20. Young WS III, Bonner TI, Brann MR (1986) Mesencephalic dopamine neurons regulate the expression of neuropeptide mRNAs in the rat forebrain. Proc Natl Acad Sci USA 83: 9827-9831

21. Moriyoshi K, Masu M, Ishii T et al (1991) Molecular cloning and characterization of the rat NMDA receptor. Nature 354:31-37

22. Monyer H, Sprengel R, Schoepfer R et al (1992) Heteromeric NMDA receptors: molecular and functional distinction of subtypes. Science 256:1217-1221

23. Kalluri HS, Mehta AK, Ticku MK (1998) Up-regulation of NMDA receptor subunits in rat brain following chronic ethanol treatment. Brain Res Mol Brain Res 58:221-224

24. Lowry O, Rosebrough N, Farr A et al (1951) Protein measurement with the folin phenol reagent. J Biol Chem 193:265-275 
25. Paxinos G, Franklin KBJ (2001) The mouse brain in stereotaxic coordinates, 2nd edn. Academic Press, London

26. Bridges RJ, Stanley MS, Anderson MW et al (1991) Conformationally defined neurotransmitter analogues. Selective inhibition of glutamate uptake by one pyrrolidine-2, 4-dicarboxylate diastereomer. J Med Chem 34:717-725

27. Herrera-Marschitz M, You ZB, Goiny M et al (1996) On the origin of extracellular glutamate levels monitored in the basal ganglia of the rat by in vivo microdialysis. J Neurochem 66: 1726-1735

28. Schepers RJ, Mahoney JL, Zapata A et al (2008) The effects of local perfusion of DAMGO on extracellular GABA and glutamate concentrations in the rostral ventromedial medulla. J Neurochem 104:806-817

29. Itzhak Y, Martin JL (2000) Cocaine-induced kindling is associated with elevated NMDA receptor binding in discrete mouse brain regions. Neuropharmacology 39:32-39

30. Kraus JE, Yeh GC, Bonhaus DW et al (1994) Kindling induces the long-lasting expression of a novel population of NMDA receptors in hippocampal region CA3. J Neurosci 14:4196-4205

31. Kamphuis W, Hendriksen H, Diegenbach PC et al (1995) Nmethyl-D-aspartate and kainate receptor gene expression in hippocampal pyramidal and granular neurons in the kindling model of epileptogenesis. Neuroscience 67:551-559
32. Ekonomou A, Smith AL, Angelatou F (2001) Changes in AMPA receptor binding and subunit messenger RNA expression in hippocampus and cortex in the pentylenetetrazole-induced 'kindling' model of epilepsy. Mol Brain Res 95:27-35

33. Pouw B, Nour M, Matsumoto RR (1999) Effects of AMPA/kainate glutamate receptor antagonists on cocaine-induced convulsions and lethality in mice. Eur J Pharmacol 386:181-186

34. Ueda Y, Tsuru N (1994) Bilateral seizure-related changes of extracellular glutamate concentration in hippocampi during development of amygdaloid kindling. Epilepsy Res 18:85-88

35. Geula C, Jarvie PA, Logan TC et al (1988) Long-term enhancement of $\mathrm{K}+$-evoked release of $\mathrm{L}$-glutamate in entorhinal kindled rats. Brain Res 442:368-372

36. Hoogland G, Spierenburg HA, van Veelen CW et al (2004) Synaptosomal glutamate and GABA transport in patients with temporal lobe epilepsy. J Neurosci Res 76:881-890

37. Wolf ME (1998) The role of excitatory amino acids in behavioral sensitization to psychomotor stimulants. Prog Neurobiol $54: 679-720$

38. Steketee JD (2005) Cortical mechanisms of cocaine sensitization. Crit Rev Neurobiol 17:69-86 